\title{
Model Test of the Effect of River Sinuosity on Nitrogen Purification Efficiency
}

\author{
Chenguang Xiao ${ }^{1, * \mathbb{D}}$, Jing Chen ${ }^{2}$, Xianjiang Yuan ${ }^{1}$, Ruidong Chen ${ }^{3}$ and Xia Song ${ }^{1}$ \\ 1 Key Laboratory of Water Conservancy and Water Resources of Anhui Province, Water Resources Research \\ Institute of Anhui Province and Huaihe River Commission, Ministry of Water Resources of the People's \\ Republic of China, Hefei 230088, China; yxj@ahwrri.org.cn (X.Y.); songxia2953@163.com (X.S.) \\ 2 Key Laboratory of Efficient Irrigation-Drainage and Agricultural Soil-Water Environment in Southern \\ China (Ministry of Education), College of Water Conservancy and Hydropower Engineering, \\ Hohai University, Nanjing 210098, China; chinsei@163.com \\ 3 School of Geography and Ocean Science, Nanjing University, Nanjing 210023, China; \\ dg1927002@smail.nju.edu.cn \\ * Correspondence: xiaochenguang@hhu.edu.cn; Tel.: +86-0551-6577-6707
}

Received: 9 May 2020; Accepted: 10 June 2020; Published: 11 June 2020

\begin{abstract}
River pollution is a significant problem within the urbanization process in China. Nitrogen is one of the most important pollutants in rivers, and the nitrogen purification capacity of rivers can be affected by their sinuous morphology. In this study, a set of sandy circulating water test models was constructed, consisting of four river channel simulation models with sinuosities of 1.0, 1.4, 1.8, and 2.2. Each model was then infused with the same concentration of nitrogen-polluted water, which circulated for $52 \mathrm{~h}$. The nitrogen reduction processes of rivers with different sinuosities were studied through water quality monitoring. The positive correlation between river sinuosity and nitrogen purification capacity was verified in physical laboratory test models. The effect of sinuosity on the spatiotemporal distribution of total nitrogen in pore water was confirmed. Additionally, the near-shore substrate was more involved in the process of river self-purification than the far-shore substrate. The concave bank of the sinuous rivers was more prone to pollutant accumulation and had a higher purification capacity than the convex bank. After the polluted water entered the sinuous channel systems, pollutant concentration differed within the convex bank between the more polluted upstream section and the less polluted downstream section. This study lays a foundation for studying the mechanism by which river sinuosity influences self-purification capacity.
\end{abstract}

Keywords: river sinuosity; river purification; water quality; nitrogen; physical modeling

\section{Introduction}

High-quality water is one of the most basic human needs. However, rapid urbanization in modern China has led to problems such as sewage discharge, lake reclamation, and river straightening, causing water quality to worsen [1]. According to statistics from the Ministry of Water Resources of China, approximately $20 \%$ of Chinese rivers currently have serious pollution problems. In particular, nitrogen content over the standard limit is a major factor in river eutrophication and water pollution [2].

The influencing factors of river water quality include the river flow state, erosion-deposition effects, turbulence effects, sediment composition, climatic conditions, sunshine duration, aquatic plant distribution, species and quantity of aquatic animals and microorganisms, etc. In particular, changes in river morphology have significant impacts on river water quality [3]. For example, river network structure and connectivity are significantly correlated with changes in river water quality [4]. According to a survey by the United Nations Environment Programme, the greater the disruption of the natural 
state and structure of rivers, the more serious the water quality deterioration. Since the late 1980s, several developed countries have investigated the effects of restoring natural river morphology on pollution control in the riverine environment [5,6]. Elosegui et al. [7] found that river morphology diversity improved the biomass of suspended aquatic organisms and significantly enhanced the self-purification capacity of a river. Kumar et al. [8] found that water blocking and hydraulic drop structures in a river could aerate the river, increase dissolved oxygen (DO) levels, and improve water quality. Higher connectivity of a river network can yield a higher water quality degradation coefficient, greater water environmental capacity, higher self-purification capacity, and better water quality [9]. The influence of river morphology changes on river ecology and purification is a current research focus [10].

To describe river morphology, the river bend curvature radius, central angle, span, amplitude, and bending coefficient are usually used to represent the plane morphology of a longitudinal meander of a river flow line [11]. Mueller [12], Leopold et al. [13], and Luchisheva [14] proposed the concepts and calculation methods of topographic sinuosity, hydraulic sinuosity, and river sinuosity, respectively, to describe the bending degree of a river. Among these descriptors, river sinuosity is the most widely used. This metric is often expressed as the ratio of the length along the central river axis to the linear distance between the upstream and downstream sections of the river [15].

To study the correlation between river sinuosity and water quality, our team selected the Shiwuli River in Hefei, China, as the research object and used a field monitoring method to analyze the relationship between the pollutant concentration reduction ratio and the river sinuosity in river sections with different sinuosities. The results showed that in natural rivers, sinuosity has different degrees of positive correlation with the growth rate of $\mathrm{DO}$ and the reduction ratios of total nitrogen (TN), ammonia $\mathrm{N}$, and total phosphorus, of which nitrogen is most significantly correlated with river sinuosity [16]. However, natural river channels are irregular, and field monitoring cannot accurately control the flow, water level, and temperature, nor can this method accurately measure and test indicators such as groundwater concentration and hyporheic exchange within the river substrate in a short time, making it difficult to explore the strength of the effect of sinuosity on water quality changes in riverine systems [17]. After building a laboratory simulation channel, Cai [18] found that changes in river morphology affected the phosphorus concentration in a river, but that research did not explore the spatiotemporal distribution of river pollutants.

Therefore, in the present study, nitrogen, which had the most significant correlation in our previous field tests, was selected as the indicator, and a set of circulating water test models was constructed, in which four sandy river channel simulation models with different sinuosities were created. To monitor the $\mathrm{TN}$ concentration in the overlying water, the nitrogen reduction process in channels with different sinuosities was investigated, and the correlation between river sinuosity and nitrogen purification capacity was tested. In addition, the effect of sinuosity on the spatiotemporal distribution of TN in pore water was investigated by monitoring the pore water quality in different locations.

\section{Methods}

\subsection{Circulating Water Test Model}

The main structure of the test model was composed of a main tank, an upstream catchment tank, and a downstream catchment tank. The main tank was rectangular and measured $440 \times 350$ $\times 50 \mathrm{~cm}$ (length $\times$ width $\times$ height). This structure was made of hollow bricks and cement mortar, with a $10 \%$ slope at the bottom of the tank. The upstream and downstream catchment tanks were constructed on the two short sides of the main tank, each connected to the main tank through a $10 \mathrm{~cm}$ wide water flume. An energy dissipator with a steady-state stable flow regime was installed behind the upstream water flume, and a sand barrier was installed at the downstream water flume. The three tank interiors were treated to be impervious to water. A multiparameter water quality analyzer and a flow-adjustable submersible pump were installed in the downstream catchment tank. 
A flow-regulating valve was installed at the outlet of the submersible pump and connected to a PVC pipe with an $8 \mathrm{~cm}$ diameter. The other end of the pipe was connected to the bottom of the upstream catchment tank. Thus, a circulating water test model (Figure 1) was built, which was powered by the submersible pump and had an adjustable flow rate.

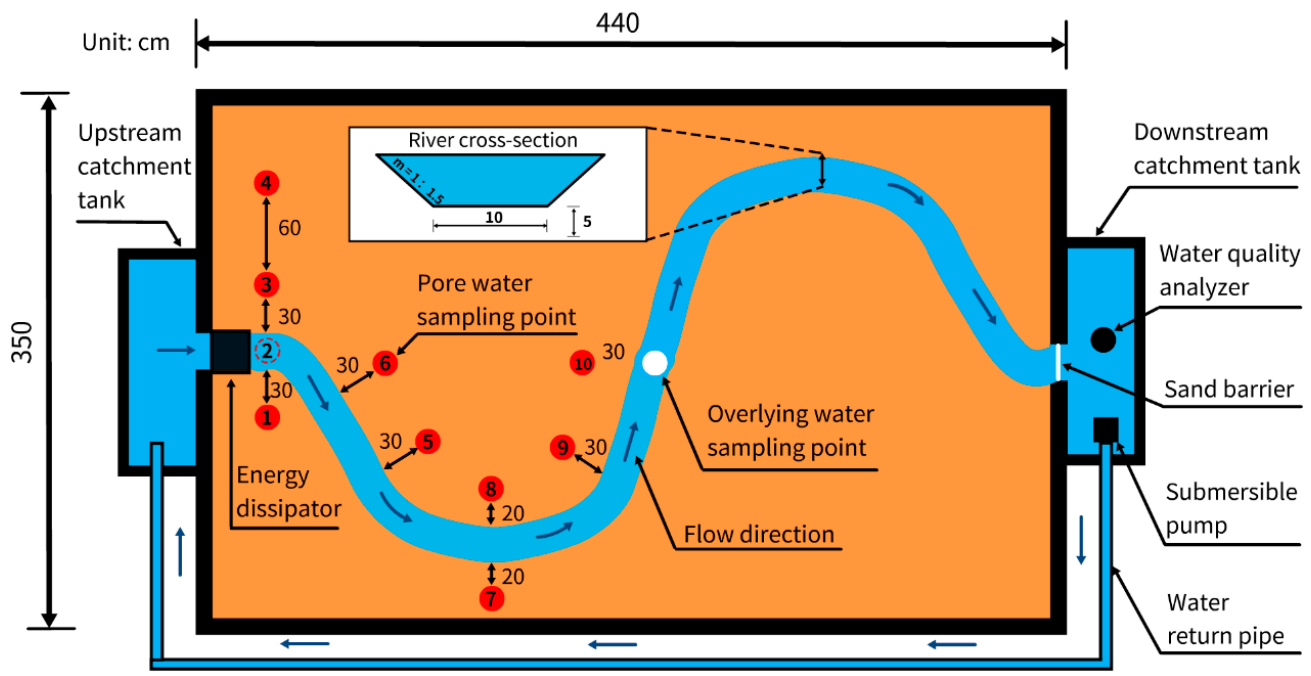

(a)

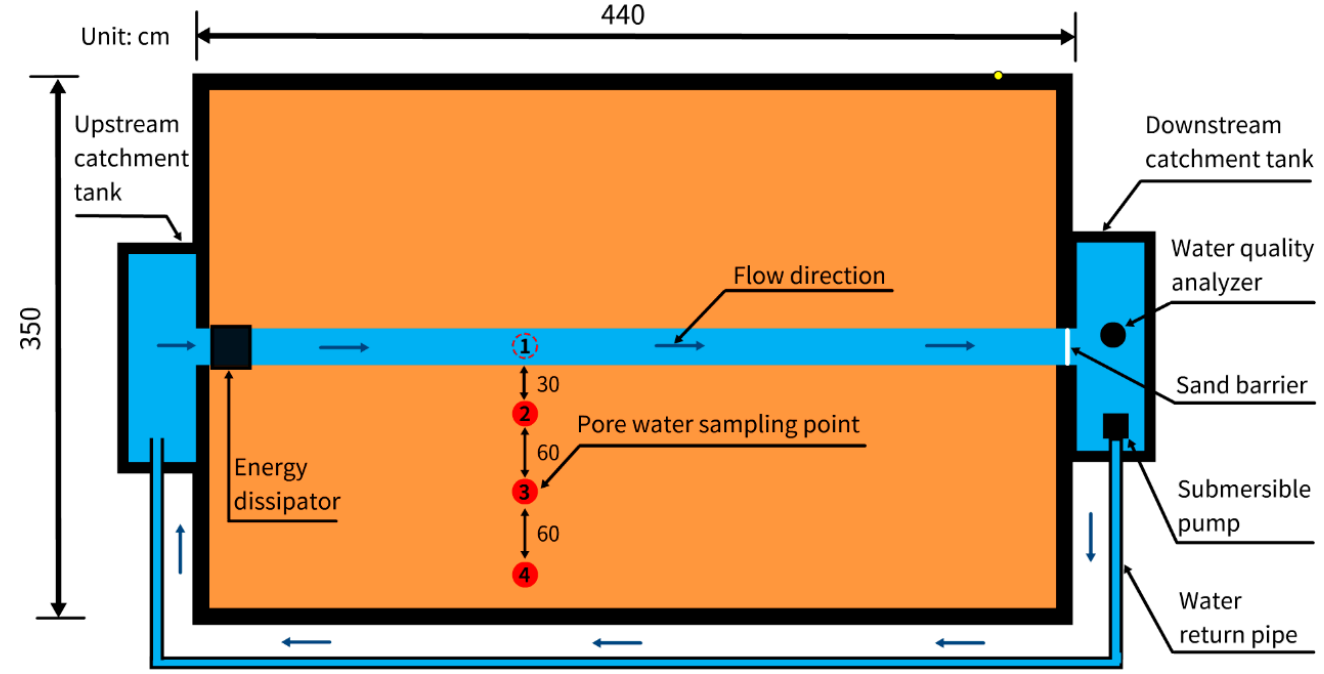

(b)

Figure 1. Circulating water test model and sampling point distribution: (a) sinuous channel and (b) straight channel.

\subsection{Experimental Methods}

Artificially prepared nitrogen-polluted water with the same nitrogen concentration was injected into the river channel models with different sinuosities for continuous circulation. Changes in the nitrogen concentration in the overlying water and pore water were monitored in each set of tests. The specific test steps were as follows.

\subsubsection{Sand-Filling and Construction of the Artificially Simulated River Channels}

Sand, clay, or other composite materials are often selected as river substrate materials in tests similar to ours. Due to the high permeability of sand, this material is conveniently used to show the diffusion pattern of pollutants in a relatively short time. Therefore, in this study, fine-grained 
yellow sand was selected as the substrate material. The sand was sourced from the Yangtze River in the Nanjing area, with an average particle diameter $\left(D_{50}\right)$ of $0.2731 \mathrm{~mm}$, a nonuniformity coefficient $\left(\mathrm{C}_{\mathrm{u}}\right)$ of 1.916 , a curvature coefficient $\left(\mathrm{C}_{\mathrm{C}}\right)$ of 0.9273 , and a permeability coefficient $(\mathrm{K})$ of $0.246 \mathrm{~cm} / \mathrm{s}$. The characteristics of the sand used in each test set were consistent. During the tests, fine sand was shoveled into the main tank, forming a $20 \mathrm{~cm}$ thick layer, and artificially simulated river channels with different sinuosities were constructed.

River sinuosity refers to the ratio of the flow length of a river to the linear distance between the upstream and downstream sections of the river. Sinuosity $(S)$ is calculated by the following formula:

$$
S=\frac{L_{T}}{L_{0}}
$$

where $L_{T}$ is the length of a river section measured along the central axis of the river, and $L_{0}$ is the linear distance between the upstream and downstream river sections. In this study, the length of the main tank was $4.4 \mathrm{~m}$. Survey results show that the sinuosity of natural rivers near towns and cities in the plains of China is usually below 2.2. Therefore, the simulated river channels with sinuosities of 1.0, $1.4,1.8$, and 2.2 constructed in this study represent an artificially straightened channel after a bend is straightened, two channels degraded due to human interference, and a natural sinuous river channel, respectively [19]. Each sinuous channel (sinuosities of 2.2, 1.8, and 1.4) had two bends. Each channel had a bottom width of $10 \mathrm{~cm}$, a bottom sand thickness of $5 \mathrm{~cm}$, and a bank slope of 1:1.5 (Figure 1).

\subsubsection{Location of the Sampling Points}

The pore water sampling points were located and marked according to the different designs. In each test set of sinuous river channels with sinuosities of 2.2, 1.8, and 1.4, 10 pore water sampling points were designated. Points 1 and 3 were located on the two opposing sides of the straight section of the channel entrance; point 2 was located on the riverbed to simultaneously obtain the overlying water concentration; point 4 was located on an extension of the line connecting points 1 and 3; points 5 and 6 were located upstream on the convex bank of the bend section, opposite of points 9 and 10 that were located downstream of the bend section; and points 7 and 8 were located on the concave and convex sides of the bend center, respectively. The specific locations of the sampling points are shown in Figure 1a with a sinuosity of 1.8 shown as an example. The locations in the models with sinuosities of 1.4 and 2.2 followed the same general principle, and the corresponding locations are similar to those shown in the figure for the sinuosity of 1.8 .

In the test of the straight channel with a sinuosity of 1.0, a total of four sampling points were designated. Point 1 was located on the riverbed, and points 2,3, and 4 were distributed on the same straight line perpendicular to the river channel. The specific locations of the sampling points are shown in Figure 1b.

\subsubsection{Water Flow Tests}

The upstream and downstream catchment tanks were fully filled with fresh water, and the submersible pump was started to pump the fresh water from the downstream catchment tank into the upstream tank, and water overflowed into the artificial channel of the main tank through the connecting flume. The water volume was adjusted until the system operated steadily and the predetermined water level was reached. The flow rate was then adjusted to $0.0002 \mathrm{~m}^{3} / \mathrm{s}$. The water flow test ended after $4 \mathrm{~h}$ of steady operation of the system, during which the conditions of the riverbed (e.g., whether the bank slope collapsed and whether the system flow was steady) were assessed. After all conditions were normalized, the fresh water in the upstream and downstream catchment tanks was drained, and the floating sand in the tank was cleaned. At this time, the simulated channel had reached a certain degree of saturation with fresh water, which is similar to the conditions of real river substrate. 


\subsubsection{Preparation and Distribution of the Microbial Solution}

In all, $15 \mathrm{~g}$ of ammonifying bacteria, $40 \mathrm{~g}$ of nitrifying and denitrifying bacteria, and $16 \mathrm{~g}$ of glucose were weighed and dissolved evenly in two $\mathrm{L}$ of water in a watering can. The bacterial solution was evenly sprayed into the main pool $10 \mathrm{~h}$ before starting the test to simulate an environment rich in carbon sources and microorganisms on a natural riparian substrate [20].

\subsubsection{Preparation of the Nitrogen-Polluted Water}

In natural rivers, $\mathrm{TN}$ mainly includes organic nitrogen, ammonia nitrogen, and nitrate nitrogen. In this study, urea $\left(\mathrm{CO}\left(\mathrm{NH}_{2}\right)_{2}\right)$ was selected to represent organic nitrogen, ammonium chloride $\left(\mathrm{NH}_{4} \mathrm{Cl}\right)$ to represent ammonia nitrogen, and calcium ammonium nitrate $\left(5 \mathrm{Ca}\left(\mathrm{NO}_{3}\right)_{2} \cdot \mathrm{NH}_{4} \mathrm{NO}_{3} \cdot 10 \mathrm{H}_{2} \mathrm{O}\right)$ to represent the nitrogen-containing solute containing nitrate nitrogen. The initial concentrations of nitrate nitrogen, ammonia nitrogen, and TN in polluted water were set as $12 \mathrm{mg} / \mathrm{L}, 15 \mathrm{mg} / \mathrm{L}$, and $35 \mathrm{mg} / \mathrm{L}$, respectively.

\subsubsection{Model Operation and Sampling Analysis}

After the nitrogen solution with a set concentration was prepared in the upstream and downstream catchment tanks, the water pump was started to run the test, the timer was started, and the flow rate was maintained at $0.0002 \mathrm{~m}^{3} / \mathrm{s}$. The overlying water and pore water were sampled regularly. The overlying water was sampled at $0 \mathrm{~min}, 5 \mathrm{~min}, 10 \mathrm{~min}, 20 \mathrm{~min}, 30 \mathrm{~min}, 45 \mathrm{~min}, 1 \mathrm{~h}, 1.5 \mathrm{~h}, 2 \mathrm{~h}, 3 \mathrm{~h}, 4 \mathrm{~h}$, $5 \mathrm{~h}, 6 \mathrm{~h}, 8 \mathrm{~h}, 10 \mathrm{~h}, 12 \mathrm{~h}, 14 \mathrm{~h}, 16 \mathrm{~h}, 24 \mathrm{~h}, 28 \mathrm{~h}, 32 \mathrm{~h}, 36 \mathrm{~h}, 40 \mathrm{~h}, 48 \mathrm{~h}$, and $52 \mathrm{~h}$, totaling 25 samples of $150 \mathrm{~mL}$ of overlying water. The pore water was sampled at each point at $0.5 \mathrm{~h}, 1 \mathrm{~h}, 4 \mathrm{~h}, 12 \mathrm{~h}, 32 \mathrm{~h}$, and $52 \mathrm{~h}$, totaling $6 \times 10=60$ samples of $10 \mathrm{~mL}$ of pore water. The pore water samples were diluted 15 -fold by adding $140 \mathrm{~mL}$ of fresh water. The TN content of the water samples was measured immediately after sampling. This monitoring method was sourced from the "Water quality-Determination of total nitrogen alkaline potassium persulfate digestion UV spectrophotometric method" [17].

The above section describes all the steps in each set of tests. After the end of each test set, the nitrogen-polluted water in the tank was drained, all the river sand was cleaned and removed from the tank, the tank was cleaned, new sand was shoveled into the tank, the sinuosity was changed, and the above steps were repeated until all four test sets were completed, with sinuosities of 1.0, 1.4, 1.8, and 2.2. The amount of sand, amount of water, flow rate, temperature, initial pollutant concentration, and amount of microorganisms added to each test set were the same at the beginning of each test, ensuring that the initial conditions were equal, except for sinuosity.

\section{Results}

\subsection{Effect of River Sinuosity on the Change in TN Concentration in the Overlying Water}

After each $52 \mathrm{~h}$ test of the reduction in nitrogen in circulating water, the TN concentrations in the overlying water were obtained for all the time points. The designated initial concentration of TN was $35 \mathrm{mg} / \mathrm{L}$, and the initial concentrations actually detected in the four test sets were between $34.41 \mathrm{mg} / \mathrm{L}$ and $35.59 \mathrm{mg} / \mathrm{L}(35 \pm 0.6 \mathrm{mg} / \mathrm{L})$. The mean flow velocity and depth of each test channel are shown in Table 1. The variation in TN concentration with time is shown in Figure 2a.

Table 1. The mean flow velocity and depth of each test channel.

\begin{tabular}{ccccc}
\hline River Sinuosity & $\mathbf{1 . 0}$ & $\mathbf{1 . 4}$ & $\mathbf{1 . 8}$ & $\mathbf{2 . 2}$ \\
\hline Mean flow velocity (m/s) & 0.041 & 0.036 & 0.032 & 0.029 \\
Mean depth $(\mathrm{m})$ & 0.032 & 0.036 & 0.039 & 0.042 \\
\hline
\end{tabular}



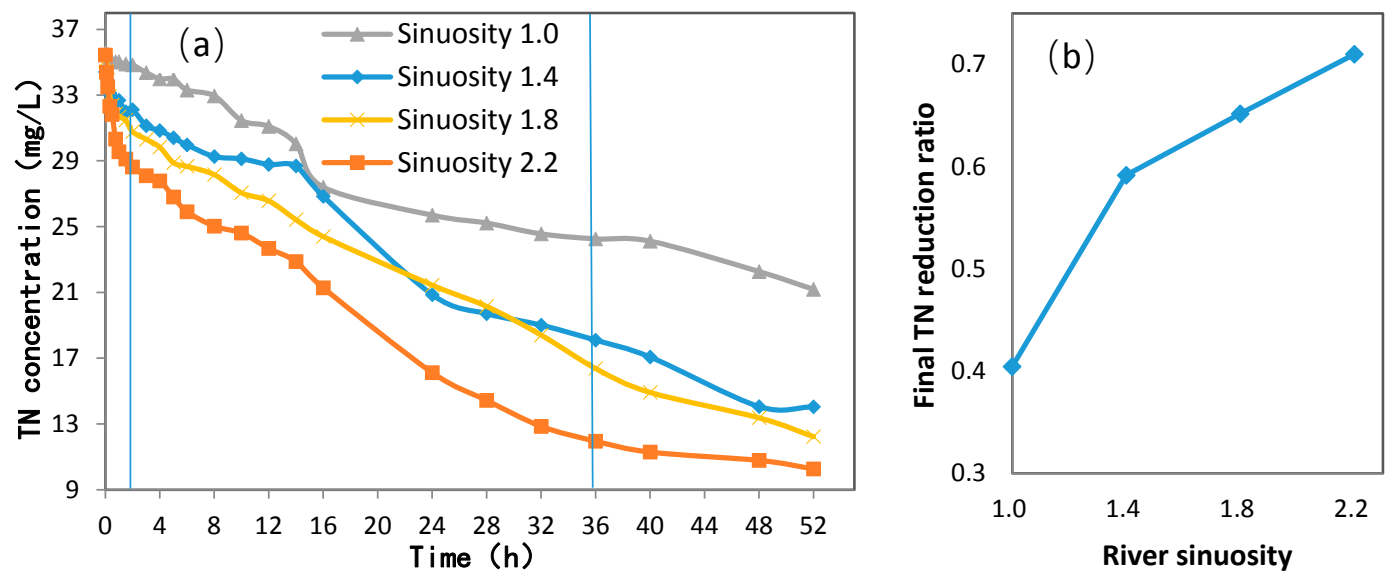

Figure 2. (a) Variation in TN concentration with time in tests with various sinuosities. (b) Relationship between river sinuosity and final $\mathrm{TN}$ reduction ratio.

The following findings were obtained based on an analysis of the tendency diagram:

(1) Owing to various physical, chemical, and biological actions in the system [21], the TN concentration in each test set decreased gradually and smoothly with the system operation, reflecting a suitable self-purification effect of the simulated river system on nitrogen.

(2) In the first test stage ( 0 to $2 \mathrm{~h}$ ), the nitrogen-polluted water fully entered the substrate and merged with the pure pore water, thereby diluting the added polluted water. The TN concentrations in the sinuous river channels (with sinuosities of 2.2, 1.8, and 1.4) all rapidly decreased, and the higher the sinuosity, the greater the decrease. However, in the straight river channel, the slope at the first stage declined gently and was significantly lower than that in any sinuous channel.

(3) In the second test phase (2 to $40 \mathrm{~h}$ ), due to the gradual completion of neutralization, each test set tended to gently slope downward, and the system was in a descending stage dominated by biochemical changes. Nevertheless, the test sets with high sinuosities still showed a faster rate of decrease. After $15 \mathrm{~h}$, the TN concentrations of sinuosities 1.0 and 1.4 showed relatively strong decreases. This finding may be due to the slower diffusion and mixing rate of pollutants in low-sinuosity channels than in high-sinuosity channels. After a period of mixing, the combination of pollutant-substrate-microorganisms-water-oxygen was more complete in low-sinuosity channels, and an optimal purification efficiency was achieved at $15 \mathrm{~h}$, resulting in a strong decrease.

(4) In the third test stage (40 to $52 \mathrm{~h}$ ), the TN concentration in the test sets with high sinuosities was already relatively low, and the reduction ratio decreased, while the reduction ratio of the test set with a straight channel was still continuously decreasing.

(5) Through comparison of the nitrogen reduction tests under different sinuosities, we concluded that in the sinuosity range between 1.0 and 2.2, river sinuosity has a significant effect on the reduction ratio and reduction rate of TN. In the tests with high-sinuosity rivers, the rate of TN decrease with time was significantly higher than in the tests with low-sinuosity rivers. Considering the relationship between the river sinuosity and the final reduction ratio of TN (Figure 2b), at the end of the test (52 h), the final reduction ratio of TN in high-sinuosity rivers was significantly greater than that in low-sinuosity rivers [22].

\subsection{Effect of River Sinuosity on the Spatiotemporal Distribution of TN in Substrate}

In the tests, the TN content was determined in pore water at specific locations in the substrate of river channels for each sinuosity. The test results are shown in Figure 3. 

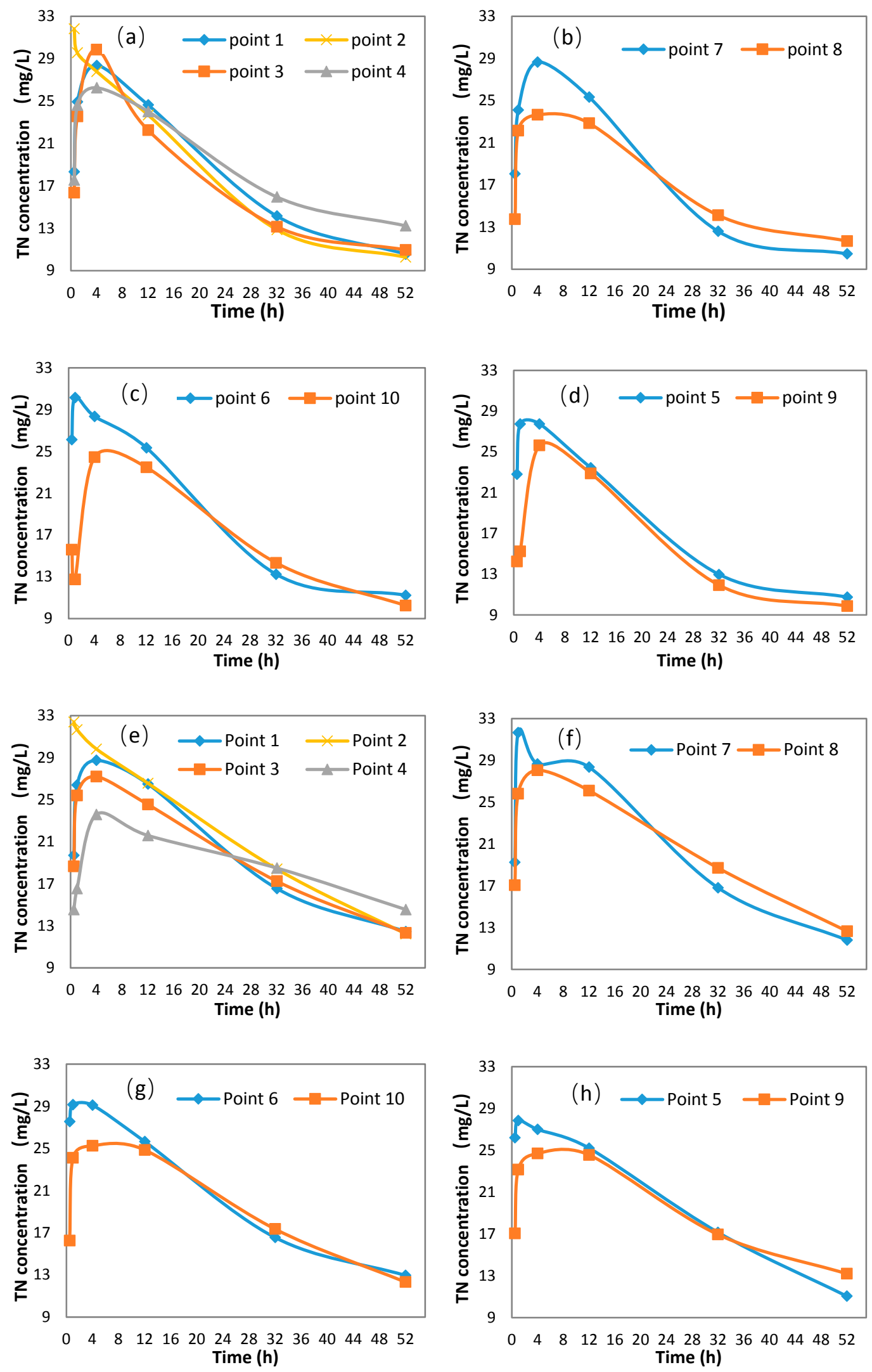

Figure 3. Cont. 

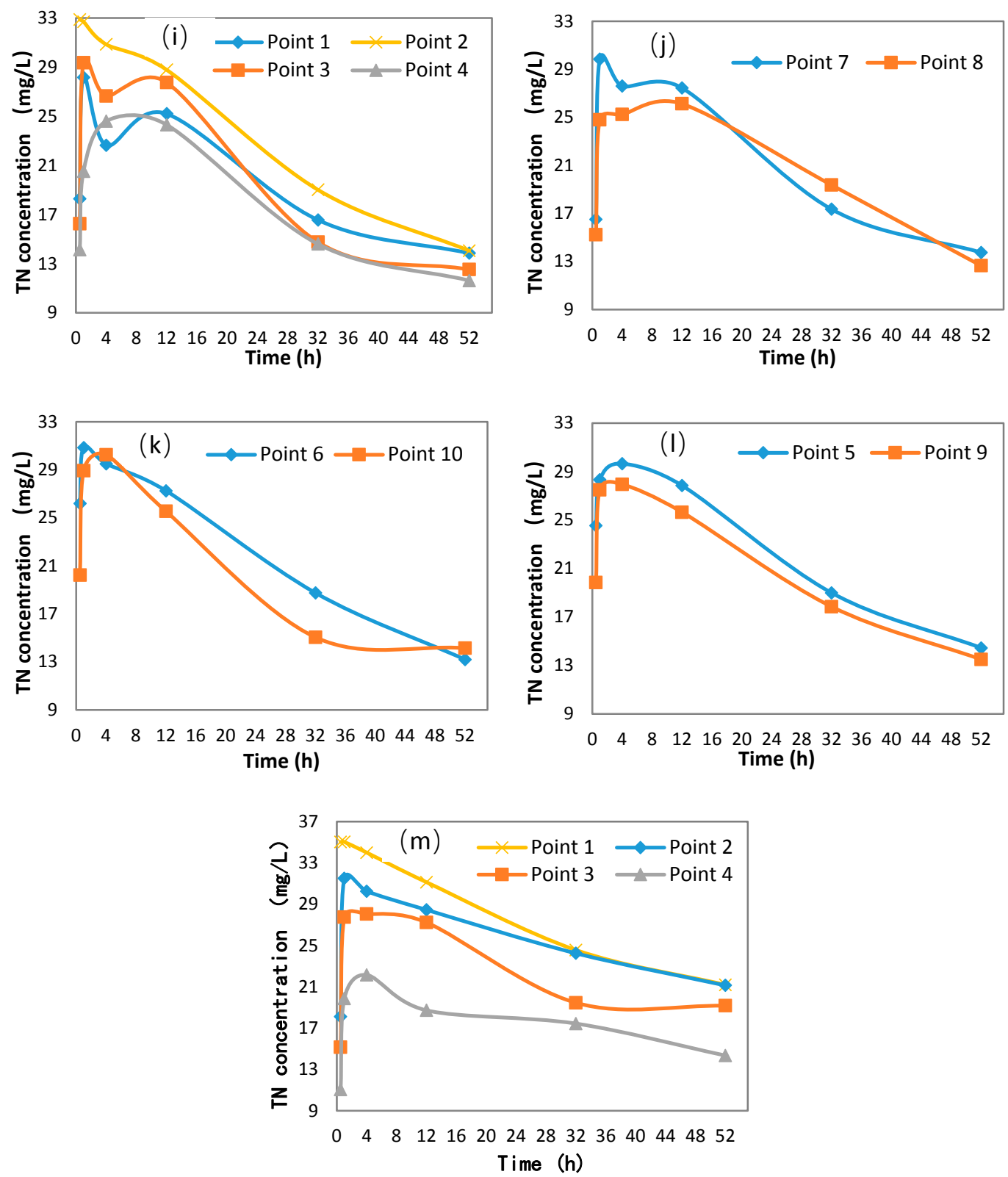

Figure 3. Variation in $\mathrm{TN}$ concentration in pore water in the test sets with sinuosities of $2.2(\mathbf{a}-\mathbf{d})$, $1.8(\mathbf{e}-\mathbf{h}), 1.4(\mathbf{i}-\mathbf{l})$, and $1.0(\mathbf{m})$.

In the sinuous channel tests (i.e., test sets with sinuosities of 2.2, 1.8, and 1.4), points 1, 3, and 4 were located in the substrate perpendicular to the direction of water flow in the straight section of the channel, and point 2 was in the overlying water. Figure 3a,e, i shows that in the first test stage ( 0 to $4 \mathrm{~h}$ ), the pore water concentrations at points 1,3, and 4 rapidly increased and that the concentrations were higher at points closer to the channel, an increase that was greater in tests with higher sinuosities. Later, the pore water concentration reached a level close to that of the overlying water (point 2) and maintained a similar decreasing process. The reason for this process of change is that a certain amount of fresh water already existed in the substrate before the start of the test. After the test started, the polluted water entered the substrate and neutralized the fresh water, causing the pore water concentration to rapidly increase until reaching equilibrium. Then, the purification effect of the system gradually decreased [23].

Points 7 and 8 were located on the concave and convex banks of the bend center of the river channel, respectively. Figure $3 b, f$, and $j$ shows that in the first stage of the sinuous channel tests, the TN 
concentration at two points increased sharply, reaching the highest level within the first 0 to $4 \mathrm{~h}$ of the test, and the concentration at point 7 on the concave bank was generally higher than that at point 8 on the convex bank. After this stage, the pollutant concentrations at both points began to decrease, and the decline in the concave bank was generally more pronounced. This result occurred because the water level rose due to a surge of water on the concave bank, so more polluted water entered the substrate of the concave bank due to the additional head, resulting in an increase in pollutant concentration. In the middle and late stages of the tests, after the pollutant concentration of the concave bank peaked, due to a more complex flow regime at the concave bank, a higher frequency of hyporheic exchange, and a higher DO level, the pollutant concentration decreased faster than at the convex bank, eventually reaching a similar level of pollutant concentration as that of the convex bank [24].

Points 5 and 6 were located on the upstream side of the convex bank, while points 9 and 10 were located on the downstream side of the convex bank. Figure $3 c, d, g, h, k$, and 1 shows that in the first stage of the tests, the TN concentration in pore water increased at all points. The TN concentrations at points 5 and 6 rose to their maximums, which were relatively high, within a short time, approximately $1 \mathrm{~h}$ after the test started. In contrast, the upward trends at points 9 and 10 were relatively delayed, as the nitrogen concentration reached the maximum level $4 \mathrm{~h}$ after the test started, and the maximum value was smaller than the peak value on the upstream side. These findings indicate that the effect of TN accumulation on the upstream side of the convex bank was stronger than that on the downstream side of the same bank. On the one hand, this result occurred because after the test started, the polluted water first passed through the upstream section and was filtered and diluted by the upstream side before flowing to the downstream side, resulting in an inherently lower concentration of polluted water absorbed by the sandy soil on the downstream side. On the other hand, the upstream side of the convex bank directly faced the incoming water flow, so more polluted water was pressed into the upstream substrate through the higher flow, resulting in a higher concentration. On the downstream side, the polluted water was only absorbed through milder hydraulic infiltration, resulting in a lower concentration. After the peak TN was reached, the trends of decreasing concentration at different points became consistent due to the more even mixing of the water body and the stability of the longitudinal hyporheic exchange [25].

In the test set in the straight channel (sinuosity 1.0), point 1 was located in the overlying water, and points 2 to 4 were located in the substrate perpendicular to the direction of water flow in the straight section of the river channel. Figure $3 \mathrm{~m}$ shows that as the distance of the substrate from the channel increased, the change in the TN concentration in the substrate significantly lagged behind that in the overlying water, indicating that the intensity of lateral hyporheic exchange in the river channel was strongly correlated with the distance of the substrate from the channel [26].

\section{Discussion}

The water quality tests in four sets of river channels with different sinuosities showed that during the $52 \mathrm{~h}$ test period, the reduction ratio of $\mathrm{TN}$ concentration in the overlying water was positively correlated with sinuosity. The greater the river sinuosity, the faster the nitrogen reduction in the overlying water and the higher the final reduction ratio.

Monitoring the spatiotemporal distribution pattern of TN in the substrate of the simulated river channels with different sinuosities showed that in the straight section, the absolute value of and variation in pollutant concentration in the substrate near the bank were highly correlated with those in the overlying water. However, in the substrate far from the channel, the change in the TN concentration of pore water lagged significantly behind that of the overlying water. This phenomenon indicates that in the straight channel, the near-shore substrate is more involved in the purification of river water than the far-shore substrate [27].

In sinuous channels, when polluted water entered the system, the concave bank of the bend section was more prone to pollutant accumulation than the convex bank. After this section, as the water flow regime at the concave bank was more complex, the rate of pollutant concentration decreased 
faster than that at the convex bank, making the concave bank an efficient pollutant treatment zone. Eventually, similar pollutant concentration levels were reached at the two banks [28].

Through comparative analysis of the pore water concentrations in the upstream and downstream sections of the convex bank of the bend section, we found that when polluted water entered the river system, the pollutant concentration in the upstream substrate of the convex bank of the bend section first increased compared with that in the downstream substrate, and this gap gradually decreased with time. In real rivers, ecological protection should focus on the upstream side of the convex bank of the sinuous channel. Such measures could include installing artificial pollution interceptors or planting water-purifying plants in response to a localized high concentration of polluted water present in a river channel [29].

The above tests show that, compared with the straight river channel, the sinuous river channels had a higher self-purification capacity. Therefore, against the current background of rapid urbanization in China, the impact of river morphology, represented by sinuosity, on the local environment must be fully considered. Rivers cannot simply be shortened to improve the land utilization rate [30]. Instead, the original natural sinuosity of river channels should be retained as much as possible to allow them to thrive. Otherwise, the economic benefits resulting from improving the land utilization rate by straitening rivers would be offset by negative effects such as environmental pollution and ecological damage [31].

\section{Conclusions}

This study established four sets of circulating water channel models with sinuosities of 1.0, 1.4, 1.8, and 2.2. The process of nitrogen reduction in rivers with different sinuosities was studied by monitoring the nitrogen concentration from pollutants in the overlying water and the spatiotemporal distribution pattern of nitrogen in pore water. The results show that (1) under laboratory conditions, there is a positive correlation between river sinuosity and TN reduction capacity; (2) near-shore substrate is more involved in river self-purification than far-shore substrate; (3) a concave bank of a sinuous river is more likely to accumulate pollutants, and its purification capacity is higher than that of a convex bank; and (4) after polluted water enters a sinuous channel system, the pollutant concentration is high in the upstream section and low in the downstream section of the convex bank, and this difference diminishes with time.

The findings of this study lay a foundation for studying the mechanism by which sinuosity affects the self-purification capacity of a river. In future experimental studies, the pollutant types could be changed to verify the relationship between river sinuosity and the reduction ratios of other pollutants. Other channel slopes with slower and faster flows and different bends with identical river sinuosity could also be addressed in future research. The effect of river sinuosity on the hydraulic state (such as turbulence effects) of a river could also be investigated to better understand the mechanism by which sinuosity affects the self-purification capacity of rivers.

Author Contributions: Conceptualization, C.X. and J.C.; methodology, C.X. and R.C.; investigation, C.X. and X.S.; resources, J.C.; data curation, C.X.; writing-original draft preparation, C.X.; writing-review and editing, C.X.; project administration, X.Y.; funding acquisition, X.Y. All authors have read and agreed to the published version of the manuscript.

Funding: This research was funded by the water conservancy science and technology project of Anhui Province: research on the key technology of comprehensive management of rural water ecology, grant number slkj2020-05.

Acknowledgments: This research was supported by Zhang from the Anhui Provincial Water Resources Department.

Conflicts of Interest: The authors declare no conflict of interest. 


\section{References}

1. Deng, X.; Xu, Y.; Han, L.; Song, S.; Yang, L.; Li, G.; Wang, Y. Impacts of Urbanization on River Systems in the Taihu Region, China. Water 2015, 7, 1340-1358. [CrossRef]

2. Xiong, G.; Wang, G.; Wang, D.; Yang, W.; Chen, Y.; Chen, Z. Spatio-Temporal Distribution of Total Nitrogen and Phosphorus in Dianshan Lake, China: The External Loading and Self-Purification Capability. Sustainability 2017, 9, 500. [CrossRef]

3. Vorosmarty, C.J.; McIntyre, P.B.; Gessner, M.O.; Dudgeon, D.; Prusevich, A.; Green, P.; Glidden, S.; Bunn, S.E.; Sullivan, C.A.; Liermann, C.R.; et al. Global threats to human water security and river biodiversity. Nature 2010, 467, 555-561. [CrossRef]

4. Chen, J.; Xiao, C.; Chen, D. Connectivity Evaluation and Planning of a River-Lake System in East China Based on Graph Theory. Math. Probl. Eng. 2018, 2018, 1361867. [CrossRef]

5. Lorenz, A.W.; Jaehnig, S.C.; Hering, D. Re-Meandering German Lowland Streams: Qualitative and Quantitative Effects of Restoration Measures on Hydromorphology and Macroinvertebrates. Environ. Manag. 2009, 44, 745-754. [CrossRef]

6. Abate, M.; Nyssen, J.; Steenhuis, T.S.; Moges, M.M.; Tilahun, S.A.; Enku, T.; Adgo, E. Morphological changes of Gumara River channel over 50 years, upper Blue Nile basin, Ethiopia. J. Hydrol. 2015, 525, 152-164. [CrossRef]

7. Elósegui, A.; Arana, X.; Basaguren, A.; Pozo, J. Self-purification processes along a medium-sized stream. Environ. Manag. 1995, 19, 931-939. [CrossRef]

8. Kumar, B.A.; Gopinath, G.; Chandran, M.S.S. River sinuosity in a humid tropical river basin, south west coast of India. Arab. J. Geosci. 2014, 7, 1763-1772. [CrossRef]

9. Schmadel, N.M.; Harvey, J.W.; Alexander, R.B.; Schwarz, G.E.; Moore, R.B.; Eng, K.; Gomez-Velez, J.D.; Boyer, E.W.; Scott, D. Thresholds of lake and reservoir connectivity in river networks control nitrogen removal. Nat. Commun. 2018, 9, 2710-2779. [CrossRef]

10. Mulholland, P.J.; Helton, A.M.; Poole, G.C.; Hall, R.O.; Hamilton, S.K.; Peterson, B.J.; Tank, J.L.; Ashkenas, L.R.; Cooper, L.W.; Dahm, C.N.; et al. Stream denitrification across biomes and its response to anthropogenic nitrate loading. Nature 2008, 452, 202-205. [CrossRef]

11. Aswathy, M.V.; Vijith, H.; Satheesh, R. Factors influencing the sinuosity of Pannagon River, Kottayam, Kerala, India: An assessment using remote sensing and GIS. Environ. Monit. Assess. 2008, 138, 173-180. [CrossRef] [PubMed]

12. Mueller, J.E. Introduction to the hydraulic and topographic sinuosity indexes. Ann. Assoc. Am. Geogr. 1968, 58, 371-385. [CrossRef]

13. Leopold, L.B.; Wolman, M.G.; Miller, J.P. Fluvial Processes in Geomorphology; Freeman: San Francisco, CA, USA, 1964; pp. 453-468.

14. Luchisheva, A.A. Practical Hydrology; Gidrometeoizdat: Leningrad, Russia, 1952.

15. Zámolyi, A.; Székely, B.; Draganits, E.; Timár, G. Neotectonic control on river sinuosity at the western margin of the Little Hungarian Plain. Geomorphology 2010, 122, 231-243. [CrossRef]

16. Xiao, C.; Chen, J.; Chen, D.; Chen, R. Effects of river sinuosity on the self-purification capacity of the Shiwuli River, China. Water Supply 2019, 19, 1152-1159. [CrossRef]

17. Jiahui, H. Study on the River Meandering Degree Impact on the River Self-purification Capacity; South China University of Technology: Guangzhou, China, 2014.

18. Cai, Y. Experimental Study on the Relationship between River Structure and Water Quality Restoration in Urban Inland River in Plain Area; Suzhou University: Suzhou, China, 2007.

19. Qing, T.Q.W.Y. Geomorphic change in Dingzi Bay, East China since the 1950s: Impacts of human activity and fluvial input. Front. Earth Sci. 2017, 11, 385-396.

20. Han, B.; Zhang, S.; Wang, P.; Wang, C. Effects of water flow on submerged macrophyte-biofilm systems in constructed wetlands. Sci. Rep. 2018, 8, 2650. [CrossRef]

21. Vagnetti, R.; Miana, P.; Fabris, M.; Pavoni, B. Self-purification ability of a resurgence stream. Chemosphere 2003, 52, 1781-1795. [CrossRef]

22. Peterson, B.J.; Wollheim, W.M.; Mulholland, P.J.; Webster, J.R.; Meyer, J.L.; Tank, J.L.; Marti, E.; Bowden, W.B.; Valett, H.M.; Hershey, A.E.; et al. Control of nitrogen export from watersheds by headwater streams. Science 2001, 292, 86-90. [CrossRef] 
23. Huang, H.; Chen, G.; Qian, F.Z. Influence of River Sinuosity on the Distribution of Conservative Pollutants. J. Hydrol. Eng. 2012, 17, 1296-1301. [CrossRef]

24. Parsapour-Moghaddam, P.; Rennie, C.D. Influence of Meander Confinement on Hydro-Morphodynamics of a Cohesive Meandering Channel. Water 2018, 10, 354. [CrossRef]

25. Cardenas, M.B. Stream-aquifer interactions and hyporheic exchange in gaining and losing sinuous streams. Water Resour. Res. 2009, 45, W6429. [CrossRef]

26. Coban, O.; Kuschk, P.; Kappelmeyer, U.; Spott, O.; Martienssen, M.; Jetten, M.S.M.; Knoeller, K. Nitrogen transforming community in a horizontal subsurface-flow constructed wetland. Water Res. 2015, 74, $203-212$. [CrossRef]

27. Cardenas, M.B. The effect of river bend morphology on flow and timescales of surface water-groundwater exchange across pointbars. J. Hydrol. 2008, 362, 134-141. [CrossRef]

28. Dwivedi, D.; Steefel, C.I.; Arora, B.; Bisht, G. Impact of intra-meander hyporheic flow on nitrogen cycling. Procedia Earth Planet. Sci. 2017, 17, 404-407. [CrossRef]

29. Yan, L.; Yan, L.; Zhang, S.; Lin, D.; Guo, C.; Wang, S.; He, Z. Nitrogen loading affects microbes, nitrifiers and denitrifiers attached to submerged macrophyte in constructed wetlands. Sci. Total Environ. 2018, 622-623, 121-126. [CrossRef]

30. Zhang, F.; Wang, J.; Wang, X. Recognizing the Relationship between Spatial Patterns in Water Quality and Land-Use/Cover Types: A Case Study of the Jinghe Oasis in Xinjiang, China. Water 2018, 10, 646. [CrossRef]

31. Vandenberghe, J.; de Moor, J.J.W.; Spanjaard, G. Natural change and human impact in a present-day fluvial catchment: The Geul River, Southern Netherlands. Geomorphology 2012, 159-160, 1-14. [CrossRef]

(C) 2020 by the authors. Licensee MDPI, Basel, Switzerland. This article is an open access article distributed under the terms and conditions of the Creative Commons Attribution (CC BY) license (http://creativecommons.org/licenses/by/4.0/). 